https://doi.org/10.31713/m1027

\title{
THE USE OF SLOPE HOISTING PLANTS TO CREATE THE CONDITIONS FOR CIRCULAR TRAFFIC OF DUMP TRUCKS
}

\author{
Slobodyanyuk V.K. \\ The National University of Kryvyi Rih, PhD (Engineering), \\ Associate Professor, the Department \\ of Open Pit Mining Operations, Ukraine
}

Slobodyanyuk R.V.

ROTATE, Co-Founder

\begin{abstract}
The purpose of this article is to develop and substantiate rational designs of slope hoisting systems for dump trucks in the open pit mines. In order to reduce the time losses associated with idle mileage in the transport cycle, it is proposed to use the slope hoisting plants only for hauling down the empty trucks. The basic arrangements of slope hoisting systems have been analyzed. A rational field of using them has been determined. The lack of experience in operation of slope hoisting systems with multi-rope friction winders, the possibility of reducing a friction ratio due to freezing and wetting the rope leave no chance to recognize this technical solution to be reliable. The article presents the results of the design study and determination of parameters of a hoister with a reeving system of suspension of one platform to haul down the 130-ton trucks. The developed hoisting plant consists of the main parts as follows: two $1-6 \times 5.6 / 0.8$ single-drum hoisters; a platform for transporting the truck; a headframe for placing the deflection sheaves; two deflection sheaves; two inclined rail tracks to move the platform. The article proposes the new technical solutions for hoisting plants with two platforms, which are alternately used for hauling down the empty trucks. The developed technology promotes improvement of the operational performance of dump trucks in the open pit mines.

Key words: slope hoisting plant, idle mileage of dump trucks, drum hoister, reeving system of vehicles, resource-saving technology

\section{Introduction}

The design depth of the Krivbas iron ore open pit mines reaches upwards of $500 \mathrm{~m}$. Pre-feasibility studies providing for an increase in the depth of open pits up to 700-1000 m are known. Under such conditions, the efficiency of open pit mining operations depends on the level of transport sophistication.

A feature of open-pit transport is one-way cargo traffic. In the transport cycle, half of the distance covered by a dump truck is
\end{abstract}


associated with idle mileage. In the $80-90$ s of the last century, a circular truck traffic arrangement with collecting the cargo en route was proposed to use at the open pits $[1,2]$. In order to use the circular truck traffic, it is necessary to create favorable conditions as follows: the sum of distances driven by a laden truck should be greater than or equal to the sum of distances driven by an empty truck. These conditions are created while in-pit dumping: the waste unloading stations are located on the dump not far from the ore faces.

The efficiency of the circular truck traffic is provided by reducing the time share associated with the run of an empty truck in its total running time. However, in the proposed version [1, 2], the circular truck traffic has a very limited area of application. The circular traffic route of open pit transport is possible with a special location of faces and delivery points for adjacent cargo flows: the loading and unloading stations for adjacent cargo flows should be located closer to each other than the loading and unloading stations for each cargo flow separately.

Another feature of deep open pits is that the mining faces are located lower than the stripping ones, and the ore unloading stations (combined transport transfer stations) are mostly located lower than the waste unloading stations. This feature of the mutual location of mining and stripping areas of the open pit and rock mass delivery points can be used as a necessary condition for the formation of an "open" (partial) circular route: mining face - ore delivery point stripping face - dump. To complete the circular route, the truck should be lowered on the working area of the open pit using equipment for hauling down the trucks [3].

The main objective of the study is to create a technology that makes it possible, when developing steeply dipping deposits, to expand the use of circular truck traffic and reduce the time share associated with the run of an empty truck in the transport cycle.

The main idea of the developed technology is to use the principle of circular truck traffic. To apply this method of truck traffic arrangement, it is proposed to use the equipment for hauling down the empty trucks into the open pit (Fig. 1). This equipment is constructed on the non-mining pit wall to haul down the empty trucks into the open pit; after hauling down, the trucks drive as follows: ore face - ore unloading station - stripping face - waste 
dump - equipment for hauling down the empty trucks into the open pit. In Fig. 1, the arrows show the direction of truck traffic during the cycle of their operation.

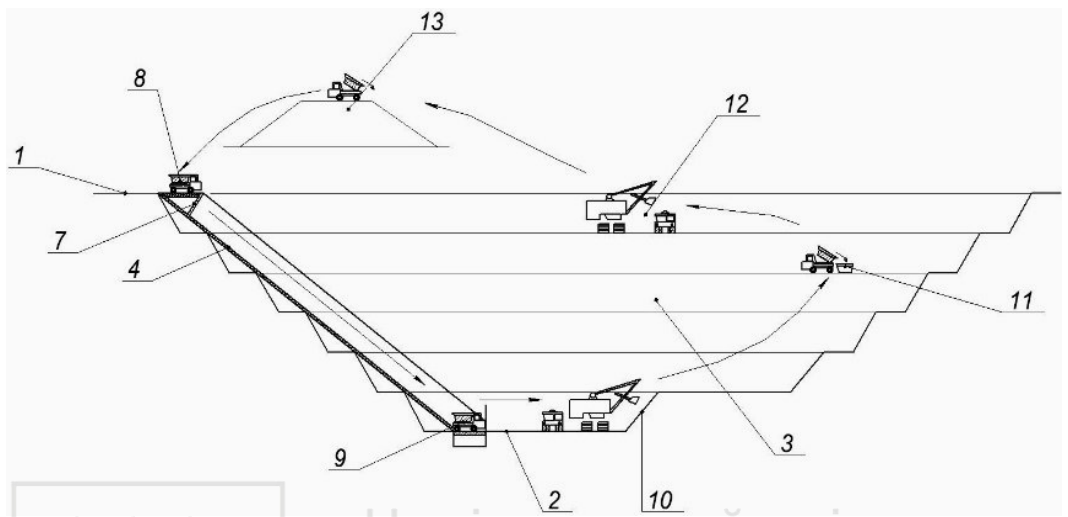

Fig. 1. The use of an equipment for hauling down the empty trucks to form a circular truck traffic in the open pit mine ( 1 - day surface; 2 - open pit bottom; 3 working benches; 4 - inclined trench; 7 - equipment for hauling down the trucks; 8 , 9 - upper and the lower positions of the platform with a dump truck; 10 - ore face; 11 - ore delivery point; 12 - stripping face; 13 -waste delivery point) [3]

\section{Experience in the use of slope hoisting plants}

By the end of the 20th century, considerable progress had been made in the development and implementation of heavy hoisting plants in the underground mines. There are examples of mines with a depth exceeding $2000 \mathrm{~m}$, the lifting capacity of hoisting plants has reached over 50-60 tons. Advances in the development of mine hoisting plants have awaken fresh interest in the use of steep-slope hoisting plants in deep open pit mines [4-12]. In the $60 \mathrm{~s}$, in the US, South America and China, more than 10 projects of slope skip hoisting plants were implemented [4-6]. In 1972, Siemag, the West German company, built the only in the USSR slope skip hoisting plant in the Sibaisky Open Pit Mine [7]. Along with the development and implementation of slope skip hoisting plants, a number of teams of authors elaborated an idea of using a slope hoisting plant to haul down the empty and lift the laden dump trucks in the open pit mines $[8-10,12]$. However, numerous projects in this regard have not been implemented. The reason for this is not only the technical complexity of slope hoisting plants, which should conform to the pit dump trucks 
in their parameters, but also the doubts about the economic efficiency of such plants at a state-of-the-art open pit. The systems designed for hauling down the empty and lifting the laden trucks are distinguished by high metal consumption and complexity of technical solutions on multi-rope hoisting.

The results of simulation of an open pit operation with a slope hoisting plant for hauling the empty and lifting the laden trucks show that two streams of trucks are formed at the open pit: the flow of empty trucks from the lower unloading station of the hoisting plant to the excavating faces, and the flow of laden trucks from excavating faces to the lower loading station of the hoisting plant. The main process feature of this flowchart is a high probability of queues of empty trucks waiting for hauling down, and laden trucks waiting for lifting out of the open pit mine. The hoisting plant acts as a limiting section of the road. A few articles [5], which have analyzed the efficiency of this type of transport, note that it is difficult to achieve and maintain the open pit capacity required. The use of the hoisting plant with only one platform to haul down alternately the empty or laden trucks initially makes a bottleneck in the transport cycle and causes the queues. It is possible to improve the technological parameters of mining operations by construction of two hoisting plants, but this will require twice as much investments. The use of this plant in an open pit mine of low capacity and with pit walls located in strong monolithic rocks can be considered as efficient. In such an open pit mine, a system of haulage roads distributed on the pit wall will be a factor that increases the amount of waste rock at the final pit.

Progress in mining machinery manufacturing has increased reliability of pit dump trucks and led to an increase in the reasonable distance of rock mass haulage. There are examples when the rock haulage by trucks reaches over $10 \mathrm{~km}$. In these conditions, the main negative factor that needs to be solved is the idle run of trucks. One-way traffic, equality of loaded and idle runs of trucks are the main features of truck haulage at the open pit; elimination of idle runs can be considered as the key method for improvement of truck haulage efficiency.

\section{Analysis of arrangements of slope hoisting plants}

A great contribution to the development of the theory of slope hoisting systems was made by V.I. Belobrov [8]. His work deals with 
multi-rope slope hoisting plants designed to haul down and lift the trucks, as well as to lift the skips of over 120 ton capacity. However, the main orientation of researches was focused on lifting the cargo to the surface. In order to solve the problem, we used a multi-rope hoisting system with a large angle of the drive sheave contact $(\alpha=3 \pi)$. With increasing $\alpha$, the lifting capacity of the hoister is increased

$$
S_{2}=S_{1} e^{\alpha f},
$$

where $S_{2}$ is the tension of the rope lifting the laden vehicle; $S_{1}$ is the same from the side of the empty vehicle; $f$ is an adhesion (friction) factor between the rope and the lining of drive sheaves (0.2-0.3).

The hoisting plants with several drive sheaves of friction have the lifting capacity by 3-6 times greater than single-drive machines. A weak point of this plant [8] is that the hoisting ropes are subjected to multiple (up to 8-9 times) kinking on the sheaves during a lifting cycle, half of them bends in different directions, that will lead to a short lifespan of the ropes.

Siemag has developed a project for a slope hoisting plant for laden trucks, which is equipped with a single platform with a counterweight [14]. In this project, a multi-rope hoisting system with a large angle of the drive sheave contact is also used.

In the world, there are several examples of using the hoisting plants for dump trucks in the mining operations under extreme conditions - in the construction of hydraulic structures in the highlands (Nant de Drance, Tokuyama, Tateyama, Miyagase, Kaprun, etc.). The capacity of these plants does not exceed 40 tons.

The main idea of this study is to increase the truck capacity by reducing the downtime associated with idle mileage in the transport cycle using the slope hoisting plants to haul down the empty trucks to the open pit [3]. Obviously, the hoisting systems equipped with two lifting platforms alternately used for hauling down the trucks can achieve maximum economic effect.

It is known that when lifting vertically using drum winders or hoisters with friction sheaves, the vehicles move in two mutually perpendicular vertical planes: in plane, where the head sheave is located, and in plane being tangential to the sheave circle (the point, where the rope leaves the sheave). The line of intersection of these 
planes coincides with the axis of the hoisting rope. When lifting vertically there are no critical difficulties with creating conditions for movement of two skips in the shaft. The skips used for vertical lifting are structurally adapted to move within a limited section of the shaft (the height of the skip is greater than its dimensions in plan).

This principle is maintained even at slope hoisting - the vehicle moves along the line of intersection of two mutually perpendicular planes, but one of them (tangent to the sheave) is located at an angle to the horizon. In this case, the design solution to arrange the movement of two vehicles (skips or platforms) associated with one or more hoisters is more complex, especially when the trucks are lowered on the platform (the length of 130-ton truck is about $12 \mathrm{~m}$, the width is $6 \mathrm{~m}$, the weight is 105 $\mathrm{t}$, the weight of lifting platform is $50 \mathrm{t}$ ). In most of proposed slope hoisting systems for dump trucks, this has led to placing the deflection sheaves on the headframes or in the hoist house that makes these hoisting plants complex and unreliable.

A great contribution to the development of the theory of slope hoisting systems was made by B.A.Nosyrev. In his work [13], eight basic arrangements of slope hoisting plants are defined, the estimation is given and the rational application area is specified. Fig. 2 shows the schematic diagrams of slope hoisting plants in the open pit mines, the analysis of these plants is given in Table 1.

The absolute lack of experience in operation of slope hoisting systems with multi-rope friction winders in the open pit environment does not optimize the possible increase in the calculated friction factor and even more than this, the friction factor may be reduced due to rope freezing and wetting during the periods of rain and snow melt [13].

\section{Engineering study of a single platform hoister}

In order to determine the main technical characteristics of the plant for hauling down the empty trucks (Fig. 3), the design was elaborated for the mining conditions as follows: type of the hoisting plant is single-end; lifting height, $H_{n}=400 \mathrm{~m}$; a slope angle of the lifting way, $\alpha=40^{\circ}$; lifting length, $L_{H}=622.48 \mathrm{~m}$; type of vehicle is a platform; capacity of the platform is $Q_{g r}=105000 \mathrm{kgf}$; mass of the platform, $Q_{\mathrm{pl}}=50000 \mathrm{~kg}$; the purpose of a hoisting plant is for men and cargo hoisting. 
The maximum static load of the slope hoisting plant is $155 \mathrm{t}$. At present, the mine hoisters manufactured by the industry have no capacity required to meet a target. The hoisting plant with two synchronized hoisters and a reeving system of suspension of the cargo platform is proposed, that will allow reducing the suspended load in the hoisting ropes. The suspended load is,

$$
Q_{0}=\frac{Q_{c m}}{n \times i_{n} \times \eta_{n}}=\frac{155000}{2 \times 2 \times 0.99}=39142, \mathrm{kgf}
$$

where $\quad n=2$ - number of hoisting ropes;

$i_{n}=2$ - mechanical advantage of a tackle block (number of ropes);

$\eta_{n}=0.99$ - efficiency of a tackle block on the roller bearings

The hoisters are divided on the principle of operation into drum hoisters and hoisters with friction sheaves. The parameters of large hoisters with a drum diameter from 4 to $6 \mathrm{~m}$ were classified as per GOST 18 115-72 standard in the Soviet mining industry. The basic drum parameters (diameter and length), the gear ratio of reducers, the maximum rope tension and static rope tension difference were subjected to standardization.

The large hoisters are designed to be installed only on the surface indoors. Fig. 4 shows the results of hoister parameter statistics as specified in GOST 18 115-72. The dependence of maximum static rope tension $\left(\mathrm{T}_{\mathrm{CT}}, \mathrm{Tc}\right)$ and the maximum static rope tension difference $\left(F_{\mathrm{CT}}, \mathrm{Tc}\right)$ on the hoister weight without a gear and electrical equipment $(\mathrm{M}, \mathrm{t})$ is determined.

The analysis (Fig. 4) shows that a parametric series of large hoisters is represented by those with a suspended load and a static tension difference upwards of 40 tons. 


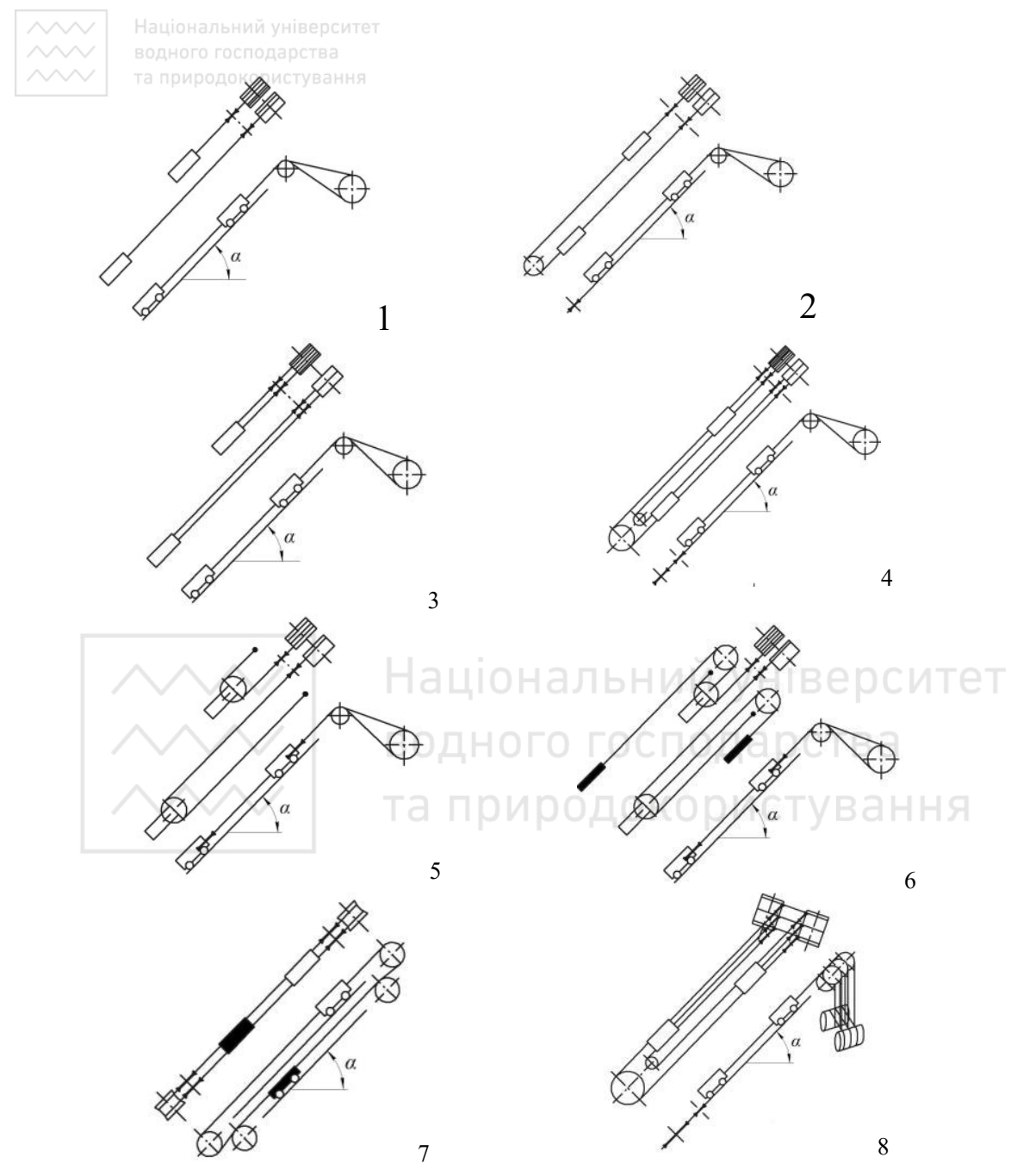

Fig. 2. Diagrams of hoisting plants [13] 
Analysis of arrangements of slope hoisting plants

\begin{tabular}{|c|c|c|}
\hline Design features & Advantages & Disadvantages \\
\hline $\begin{array}{l}\text { A single-rope hoisting } \\
\text { plant with multilayer rope } \\
\text { winding on a cylindrical } \\
\text { hoist drum (Fig. } 2.1,2.2 \text { ), } \\
\text { (drum hoist). Capacity is } \\
\text { up to } 40 \mathrm{t} \text {. }\end{array}$ & $\begin{array}{l}\text { Simplicity and } \\
\text { reliability of the plant; } \\
\text { the possibility of using } \\
\text { the lubricated ropes. }\end{array}$ & $\begin{array}{l}\text { The use of this plant is limited by } \\
\text { traction properties of the rope, the } \\
\text { static tension of the rope line and } \\
\text { the greatest static unbalanced } \\
\text { circumferential force. With a } \\
\text { greater unbalanced } \\
\text { circumferential force, it is } \\
\text { necessary to balance the hoisting } \\
\text { system. }\end{array}$ \\
\hline
\end{tabular}

A multi-rope hoisting Simplicity and When lifting cargo from deep plant with multilayer rope reliability of the plant; levels, the improvement of winding on the section of the possibility of using energy effect may be achieved by cylindrical drums (Fig. the lubricated ropes, using lower balancing ropes (Fig. 2.3), (Blair hoist). the use of a winding 2.4).

Capacity is over 40t, reel of smaller lifting height is over diameter than in the $400 \mathrm{~m}$. $\quad$ case of friction sheaves.

The hoisting plants with a The harmful Complication of the vehicle reeving system of phenomenon 100 of construction due to placing the suspended vehicles (Fig. uneven force circumferential sheave on its $2.5,2.6)$. \begin{tabular}{l|l} 
distribution along the & frame, an increase in the vehicle \\
rope lines has been & weight by $10-15$ tons; increased \\
eliminated; due to the & wear of the rope, because of the \\
high speed of the rope, & doubled speed of its movement \\
it is possible to use & and additional bending on the by- \\
gearless drives. & pass sheave; the use of double- \\
The use of block & length ropes. \\
hoisting arrangements & \\
is reasonable for cage \\
hoisting plants with a \\
low lifting speed of \\
the cage (platform).
\end{tabular} A multi-rope hoisting It can be used with Limited use due to the rope stress plant with friction long ropes; decrease ratios; increase in wear and sheaves (Fig. 2.7, 2.8), in inertial masses of corrosion of the rope due to the (Koepe hoists). Capacity the winding reel; lack of protective lubrication; is over $40 \mathrm{t}$, lifting height increase in efficiency reduction of the friction factor is over $400 \mathrm{~m}$. A hoister of the hoisting plant; due to rope freezing and wetting with one driving friction rope rupture hazard during the periods of rain and sheave provides no high prevention when the snow melt; constructive $\underline{\text { traction and requires the }}$ vehicle is derailed/complexity of two-vehicle slope 


$\begin{aligned} & \text { balancing ropes. In the } \\
& \text { hoisters with several } \\
& \text { driving friction sheaves, } \\
& \text { the angle of the drive } \\
& \text { sheave contact is } 3 \pi .\end{aligned}$
\begin{tabular}{l} 
lifted. \\
\hline
\end{tabular}

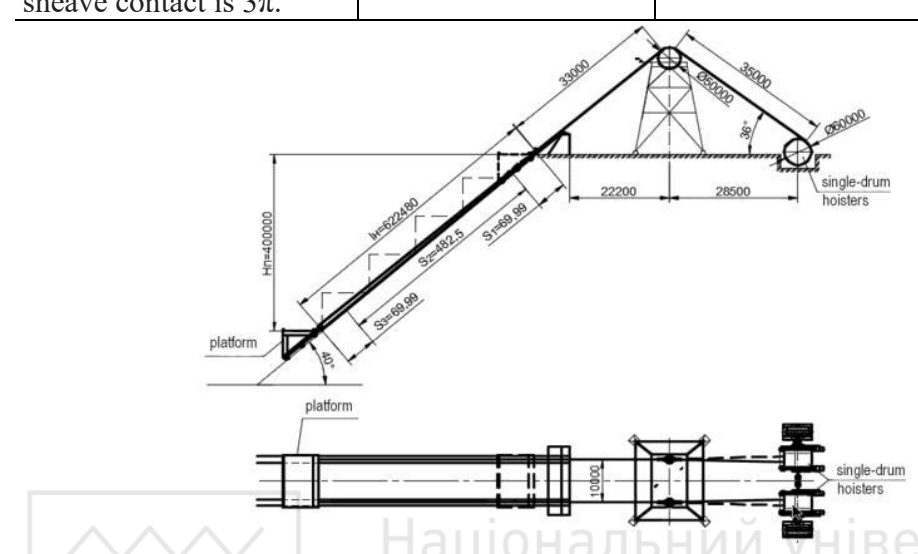

Fig.3. Diagram of a hoisting plant

As a hoister, it is rational to use the mine hoister with one cylindrical drum that has been developed by NKMZ. Based on the dimensions of the winding reel and suspended loads, the $1-6 \times 5.6 / 0.8$ mine hoister fits good having the parameters as follows: $6000 \mathrm{~mm}$ drum diameter; $5600 \mathrm{~mm}$ drum width; $560 \mathrm{kN}$ static rope tension; $400 \mathrm{kN}$ difference in static rope tension and $11200 \mathrm{kNm}^{2}$ flywheel effect.
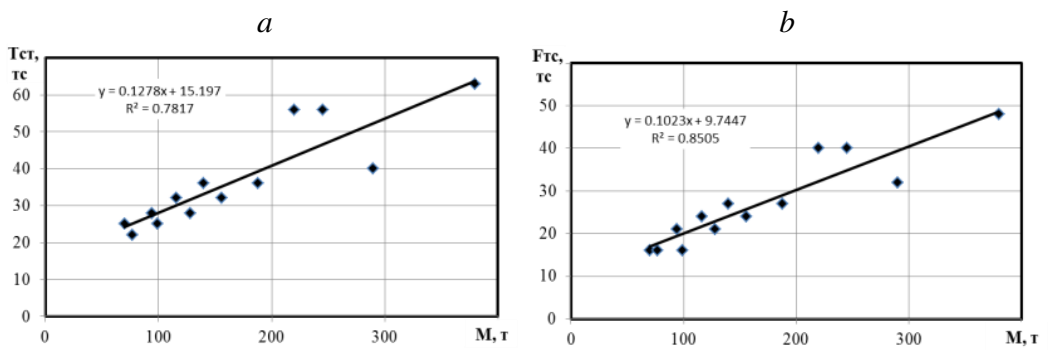

Fig. 4. Dependence of the maximum static rope tension (a) and the maximum static rope tension difference (b) on the hoister weight

The developed hoisting plant consists of the following parts: 
- two 1-6×5.6/0.8 single-drum hoisters;

- platform for transporting the truck;

- a headframe for placing the deflection sheaves;

- two deflection sheaves (Ø $5000 \mathrm{~mm}$ );

- two inclined rail tracks to move the platform.

In order to reduce the suspended load on the hoisting ropes, provision is made for two hoisters with fixing the ropes via a tackle block to the platform frame. This type of arrangement makes it possible to use commercially available hoisters. In order to distribute an even load, the operation of hoisters should be synchronized in terms of rope speed and tension. The parameters of the hoisting plant are determined by calculation as follows: the hoisting speed is 9.9 $\mathrm{m} / \mathrm{s}$, one cycle time is $214.2 \mathrm{~s}$, the time for a truck to drive on and off the platform is $60 \mathrm{~s}$, number of cycles per hour is 12-15. Fig. 5 shows the diagrams of acceleration, speed and force.

When the loaded platform is lowered, $1 \div 3$ periods (Fig. 5), the values of driving forces on the circumference of the rope winders have negative values, i.e. the engines operate in a dynamic braking mode. When the platform is lifted, the drive motors operate in a traction mode, overcoming the static resistance of the hoisting system and at the same time ensuring the actual linear speed with the proper acceleration and deceleration adopted according to the requirements of design standards.

The hoisting plant is equipped with two P2-800-217-8SUHL4 electric motors of $3150 \mathrm{~kW}$ nominal.

\section{Study of slope hoisting plants with two platforms}

The efficiency of mining operations with the use of a developed system for hauling down the trucks on the working area depends on the number of downward trips per hour. The performance of the hoisting plant with one platform is sufficient to provide operation of one shovel with a $12-15 \mathrm{~m}^{3}$ bucket capacity. In order to provide a working area of the open pit with twice as many trucks, it is necessary to build two similar single-rope hoisting plants or to develop a hoisting plant with two platforms. The main idea that needs to be implemented in the hoisting plant with two platforms is 
to balance the hoisting system and haul down the trucks while engines are operating in a regeneration mode.

The arrangements can be classified as per location of tracks with respect to the longitudinal hoister and as per position of tracks relative to each other. We will compare the advantages and disadvantages of alternative arrangements of hoisting plants having two platforms with two independent hoisting plants having one platform.

Analysis of possible kinematic diagrams allowed the following solutions to be called competitive. From the position relative to the hoister, both tracks can be located either on one side (Fig.6, 7) or on opposite sides of the hoister (Fig.8). When the tracks are located on opposite sides of the hoister, they are located in the same vertical plane, but not parallel to each other (Fig.8). In order to ensure mining technical conditions for this track location, it is necessary to provide a site for the hoister on a rock pillar, protruding in plan from the general strike trend of the pit wall. With this design of the hoisting plant, it becomes possible to haul down the trucks at two different sections of the working area. The distance between in-pit sites of the hoisting plant can reach $600-800 \mathrm{~m}$. When the tracks are located on one side of the hoisting plant, they are also located in the same plane, in general, parallel to each other, but this plane can be either parallel to the pit wall plane (Fig.6), or be vertical and pass through the hoisting sheaves of the hoisting plant (Fig.7).

Fig. 7 shows a general view of the hoisting plant with one-sided arrangement in vertical plane of two parallel tracks (the top and bottom tracks), where 1,2 - platforms; 3 - dump truck; 4,5 - inclined rail tracks; 6,12 - hoisting ropes; 7,13 - headframes; 8,14 - top headframe sheaves; 11,17 - bottom headframe sheaves; 9,15 - rope winding reel; 10,16 - electric motors; 18 - a hoist house (deflection sheaves on the platforms and a reeving system are not shown in the figure). 


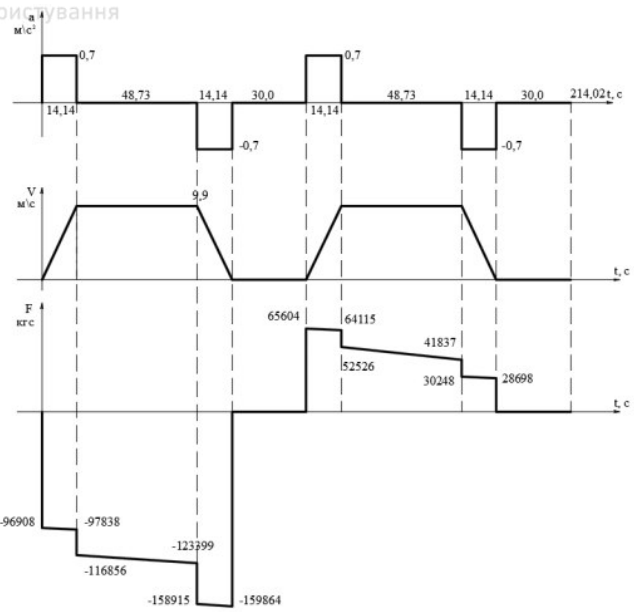

Fig. 5. Diagrams of acceleration, speed and force

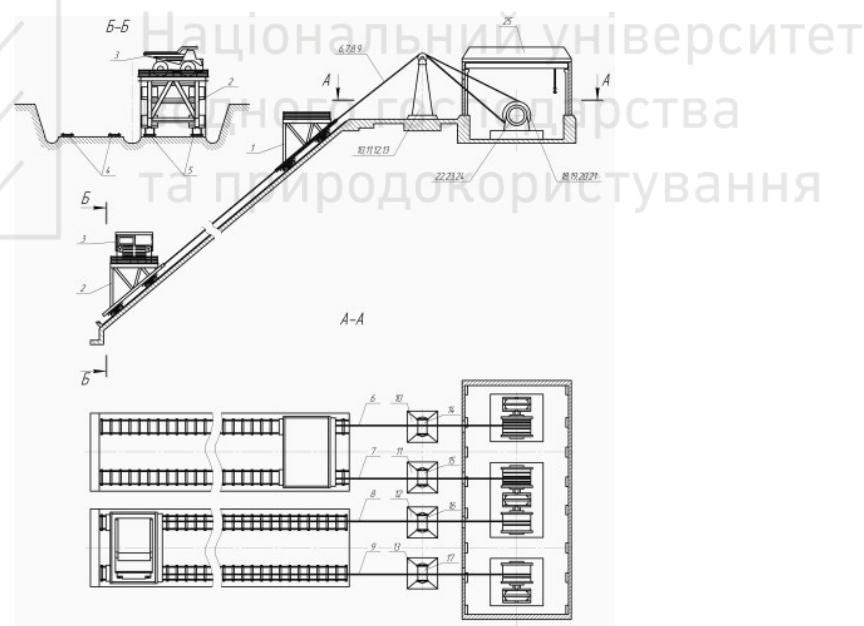

Fig. 6. General view of a hoisting plant with a single-sided arrangement of two parallel tracks in plane of a pit wall 


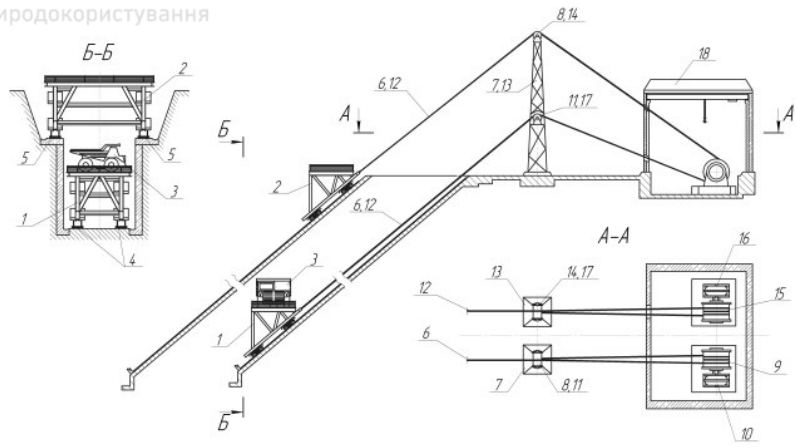

Fig. 7. General view of a single-sided hoisting plant in vertical plane of two parallel tracks

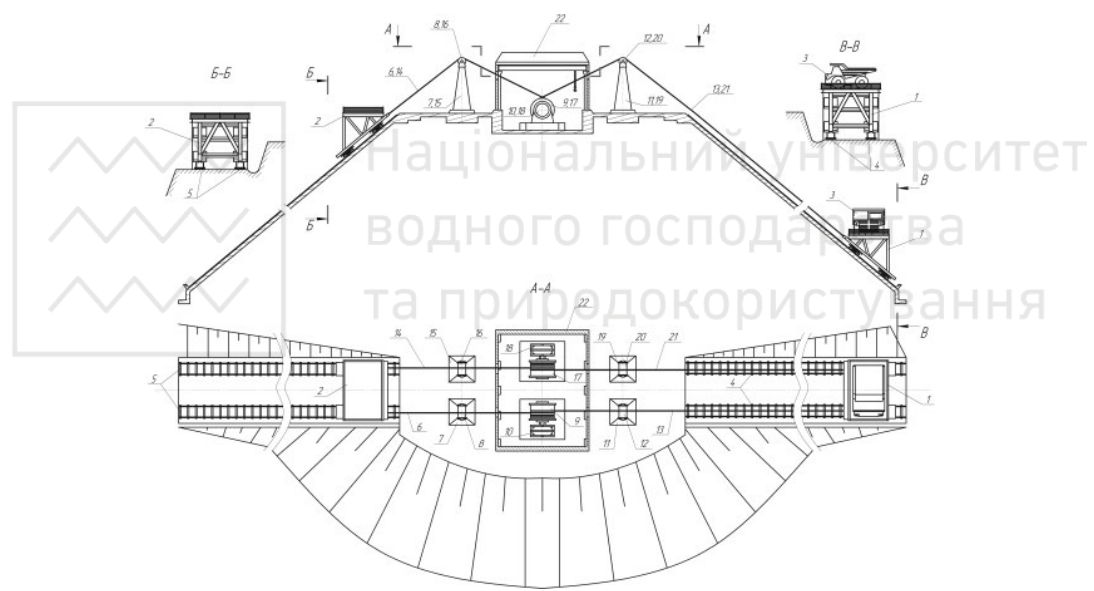

Fig. 8. General view of a hoisting plant with an opposite-sided arrangement of two parallel tracks in vertical plane

Fig. 8 shows a general view of the hoisting plant with an oppositesided arrangement (in relation to vertical plane passing through the longitudinal axis of the drum) in vertical plane of two tracks (conditionally applied to Fig.8, left and right tracks), where 1 is platform of the right track; 2 - platform of the left track; 3 - dump truck; 4,5 - inclined rail tracks; 6,14,13,21 - hoisting ropes; 7,15,11,19 - headframes; 8,16,12,20 - headframe sheaves; 9,17 rope winding reels; 10,18 - electric motors; 22 - a hoist house (deflection sheaves on the platforms and a reeving system are not shown in the figure). 
The arrangement shown in Fig. 6 differs from two independent, side-by-side located hoisting plants with one platform in that the adjacent single-drum hoisters are replaced by one double-drum hoister. The double-drum hoister serves both tracks and operates all the time in a regeneration mode, the single-drum hoisters operate alternately. In this case, the hoisting plant is equipped with three hoisters. One of the main drawbacks of this arrangement is that there is no possibility to provide a through movement of trucks, that is, when driving on or off the platform, the truck drives in reverse.

The diagram in Fig. 7 differs from the diagram in Fig. 6 in that the hoisters are statically more balanced; the ropes are pairwise wound on the cylindrical drums: when one rope reels in, another one reels out. Two hoisting plants provide hauling two platforms up and down, and operate all the time in a regeneration mode. The location of tracks in section of one step-shaped trench allows the trucks to arrive and depart without additional maneuvers. The drawback of this arrangement is the need to construct a special trench with the rail tracks at two levels. The upper platform is structurally more complex than the lower one.

The diagram shown in Fig. 8, in terms of arrangement of hoister operation is substantially similar to the diagram in Fig.7. However, in this case, two tracks of the hoisting plant are located in diametrically opposite directions. This design is characterized by a safer arrangement of the truck movement on the upper loading station and provides driving the trucks off the platform in the lower position without additional maneuvers. This arrangement is characterized by a large amount of mining and capital work to prepare the construction sites for a hoist house and a track and can be used at the open pits with a long-distance haulage.

\section{Conclusions}

The article presents the results of researches on the development and substantiation of rational designs of slope hoisting systems for hauling down the empty dump trucks in the open pit mines, the use of which will reduce the idle runs. Decrease in idle runs in the transport cycle of trucks is one of the most promising ways to maintain and increase the open-pit transport capacity. 
The basic arrangements of slope hoisting plants using drum hoisters and hoisters with friction sheaves have been analyzed. The design complexity of slope hoisting plants with friction sheaves, the rope exposure to atmospheric precipitation (wetting and frosting), increased rope wear due to friction against the supporting rollers and sheaves cause the low reliability of this hoisting plant. The hoisters with cylindrical drums are free from above drawbacks. The issue of providing the required hauling ability of the hoisting plant is proposed to be solved by using several drum-type hoisters in its construction.

The results of design study of the hoisting plant for hauling down the empty trucks of 130-ton capacity are presented. The arrangement of the hoisting plant with two synchronized drum hoisters and a reeving system of suspension of one cargo platform that allows reducing the suspended load in the hoisting ropes is considered. The developed hoisting plant consists of the main parts as follows: two 16x5.6/0.8 single-drum hoisters (manufactured by NKMZ); a platform for transporting the truck; a headframe for deflection sheaves; two deflection sheaves; two inclined rail tracks for moving the platform. When lowering the dump trucks, the hoisters operate in generator mode that allows for electrical energy regeneration.

The efficiency of mining operations with the use of a developed system for hauling down the trucks on the working area depends on the number of downward trips per hour. In order to provide a working area of the open pit with more trucks, it is necessary to build two similar hoisting plants or to develop a hoister with two platforms. The article proposes the new technical solutions for hoisters with two platforms, which are alternately used for hauling down the empty trucks. The developed technology promotes improvement of the operational performance of trucks in the open pit mines.

\section{References}

1. Astafiev J.P. (1991). Model marshrutizatsii avtosamosvalov pri rabote $\mathrm{s}$ vnutrikaryernymi punktami razgruzki [Model of dump truck routing when working with in-pit unloading stations], Razvitie teorii otkrytyh gornyh rabot. Moscow [in Russian].

2. Astafiev J.P., Maksimov A.V. (1992). Organizatsiya avtotransportnykh potokov v glubokikh kar'yerakh po printsipu kol'tsa [Arrangement of circular-based truck traffic flows in the deep open pit mines]. Razrabotka rudnyh mestorojdeniy: 
nauchno-tehnicheskiy sbornik - Development of ore deposits: scientific and technical collection. Kiev [in Russian].

3. Sposib rozkryttya krutospadnykh rodovyshch pry vidkrytiy rozrobtsi korysnykh kopalyn: patent No. 117930 Ukraina - The open pit mining method of steeply dipping deposits: the patent of Ukraine (20 years) No. 117930 [in Ukrainian].

4. Shilling R., Adams B. (1971). Naklonnye skipovye pod"emniki [The inclined skip hoists]. Nauchn. tr. amerikanskogo instituta gornyh inzhenerov, inzhenerov-metallurgov i neftyanikov. Moscow: Nedra [in Russian]

5. Build Unique Truck Skip Hoist in Belgian Congo. Mining World. 1959. №6.

6. Novozhilov M.G., Selyanin V.G., Trop A.E. (1962). Glubokie kar'ery [Deep open pit mines]. - M: Gosgortekhizdat [in Russian]

7. Vasil'ev M.V. (1975) Ustrojstvo, opyt ekspluatacii i perspektivy kar'ernogo skipovogo pod"ema [Arrangement, operating experience and prospects of skip hoisting] . Tr. IGD MChM SSSR. Vyp. 46. [in Russian].

8. Belobrov V.I., Belobrova E.A. (2002). Mnogokanatnye naklonnye pod"emnye ustanovki dlya kar'erov i shaht [Multi-rope slope hoisting systems for open pits and underground mines]. Nauk.-tekhn. zb. «Girnicha elektromekhanika ta avtomatika». №69. [in Russian].

9. Bondariev S.V., Horbatenko Yu.P.(2011). Zastosuvannia pidiimachiv dlia peremishchennia avtomobiliv po krutykh skhylakh [The use of hoists to relocate the trucks on steep slopes] . Budivnytstvo Ukrainy. № 1. [in Ukrainian].

10. Dremin A.I., Perepelicyn A.I., Krutikov N.N. (1993). Pod"emnik dlya dostavki gruzhenyh avtosamosvalov so dna kar'era na poverhnost'. [A hoist for delivery of laden dump trucks from the open pit bottom to the surface] . Gornyj zhurnal. № 7. [in Russian].

11. Kul'bida P.B., Rojzen V.V., Serbin V.I. (1981). Bol'shegruznye skipovye pod"emniki dlya otrabotki glubokih kar'erov [Heavy-duty skip hoists for deep open pit mines]. Gornyj zhurnal. № 7. [in Russian].

12. Listopad G.G. (2001). Naklonnye pod"emniki kar'ernogo avtotransporta [The slope hoisters for dump trucks in the open pit mines]. Gornaya promyshlennost'. № 2. [in Russian].

13. Nosyrev B.A. (1972). Skhemy kar'ernyh naklonnyh pod"emnyh ustanovok, ih ocenka i oblasti primeneniya [Arrangement of slope hoisting plants in the open pit mines, assessment and application]. Trudy Sverdlovskogo gornogo instituta. Vyp. 97 [in Russian].

14. Trucklift System. Innovative transport technology for open pit mines. URL:http:/www.siemag-tecberg.com/infocentre/ technical-information/ti_27trucklift.html (accessed 25 May 201 